\title{
The significance of human induced and natural erosion features (lavakas) on the central highlands of Madagascar
}

Michael S. Zavada, Yeqiao Wang', Gérard Rambolamanana", Andriamiranto Raveloson" and Hélène Razanatsoa"'

\begin{abstract}
Massive hill slope erosion in Madagascar is represented by the widespread gullies called 'lavaka'. Lavakas may be result of natural processes that involves a combination of continuous tectonic uplift that maintains a high angle of repose, ground water sapping at the soil-saprolite interface, and subsequent collapse of the soil surface due to low grade seismic activity in the central highlands. Forest cover ranges between $25-45 \%$ in the study area and is primarily restricted to riparian and lavaka habitats. Development of forest cover associated with riparian and lavaka habitats may be due to increased soil moisture, exposure of a less nutrient poor saprolite and/or soil compaction. In addition, riparian and lavaka habitats harbor a significantly higher diversity of plant species than the surrounding grasslands. Lavakas may be a result of natural processes and may play a role in the development of Madagascar's landscape evolution.
\end{abstract}

\section{RÉSUMÉ}

Les formes d'érosion connues sous le terme de lavakas peuvent être le résultat d'un processus naturel impliquant à la fois un soulèvement tectonique continu qui maintient un angle de repos important, un processus de sape des eaux souterraines à l'interface sol - saprolite et un effondrement consécutif de la surface du sol du à la faible activité sismique des hautes terres du centre. Ce phénomène est suivi d'une succession géomorphologique à long terme et d'une succession de végétation liées aux lavakas, de sorte que les lavakas et la végétation qu'ils abritent sont isolés du bassin versant principal. Les rivières et les bassins versants en tant qu'éléments séparateurs ont, semble-t-il, joué un rôle dans la richesse de la biodiversité de Madagascar. La présente étude montre que la végétation associée aux forêts riveraines et aux lavakas représente $25-45 \%$ de la couverture forestière des hautes terres du centre. L'absence de forêts sur les zones herbeuses voisines ou la présence d'une succession de végétation liée aux zones herbeuses suggère que le développement de la végétation arborée pourrait être lié à des changements du degré d'humidité du sol, de la disponibilité des éléments nutritifs ou du tassement du sol. Le taux d'humidité s'est avéré être constant dans tous les habitats échantillon-
Correspondence:

Michael S. Zavada

East Tennessee State University, Department of Biological

Sciences, Box 70703, Johnson City, TN 37615, USA

E-mail: zavadam@etsu.edu

nés. La disponibilité en éléments nutritifs peut jouer un rôle dans la structure de la végétation. Les lavakas se formant par l'effondrement du sol superficiel par un processus de sape des eaux souterraines à l'interface sol - saprolite, la zone racinaire de la végétation se trouve alors à proximité des saprolites pauvres en éléments nutritifs. Le degré de tassement du sol diffère de manière significative entre les forêts ripicoles/lavakas et les zones herbeuses. Les zones herbeuses ont montré des mesures de résistance du sol au pénétromètre élevées (moyenne de $17,9)$ et un profil de tassement qui peut limiter le développement racinaire d'un certain nombre d'espèces. Les mesures effectuées dans les forêts riveraines et les lavakas étaient respectivement de 14,0 et 9,7 qui sont des valeurs compatibles avec un développement racinaire. De ce fait, les différences entre les structures de la végétation et la diversité peuvent trouver leur origine dans la capacité des plantes à développer leur système racinaire. II existe également un rapport inverse entre la diversité spécifique et le degré de tassement du sol dans les trois habitats. La mobilité des sols dans les lavakas et les habitats ripicoles peut réduire le tassement en surface et juste en dessous en favorisant ainsi un labourage naturel. Les lavakas peuvent ainsi être le résultat d'un processus naturel et jouer un rôle important dans le développement de l'évolution des paysages de Madagascar et de la biodiversité.

KEYWORDS: Madagascar, lavaka, landscape evolution, geomorphology, riverine forest.

MOTS CLEF : Madagascar, lavaka, évolution des paysages, géomorphologie, forêt riveraine.

\section{INTRODUCTION}

International aid and development agencies have designated Madagascar's erosion rate the highest in the world (e.g., WorldBank/USAID/CooperationSuisse/UNESCO/UNDP/WWF1986, United States Agency International Development (USAID) 1998). Annual erosion rates are estimated at 200-400 tons / ha, 20-40 times above the world average (Enquêtes Prioritaires auprès des Ménages 1999). Massive hill slope erosion is represented by the extraordinary and widespread gullies called 'lavaka' (Tricart 1953) from the Malagasy word for 'hole'. Heavy sediment 


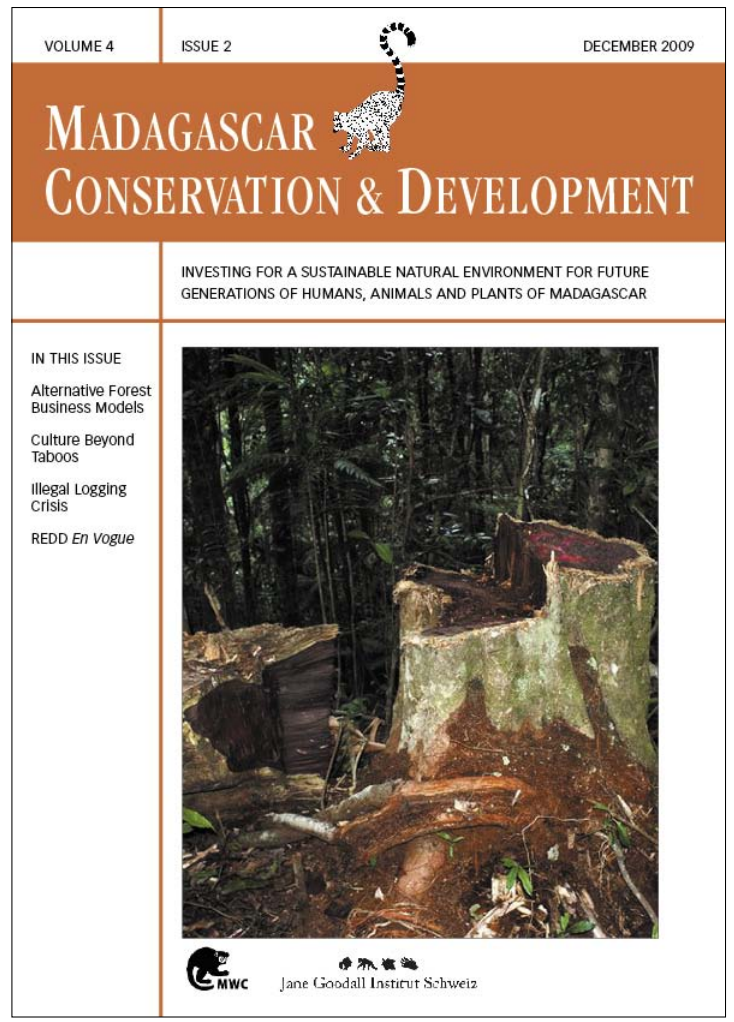

Madagascar Conservation \& Development is the journal of Madagascar Wildlife Conservation (MWC) and the Jane Goodall Institute (JGI Switzerland). It is produced in these institutions' own responsibility.

All the Issues and articles are freely available at http://www.mwc-info.net/en/services/journal.htm

Contact Journal MCD

info@journalmcd.net for general inquiries MCD funding@journalmcd.net for supporting the journal

Journal Madagascar Conservation \& Development Institute and Museum of Anthropology University of Zurich

Winterthurerstrasse 190

$\mathrm{CH}-8057$ Zurich, Switzerland

contact@mwc-info.net for general inquiries

Postfach 2701

CH-8021 Zürich, Switzerland

Logement 11, Cité Andohaniato

Antananarivo 101, Madagascar

info@janegoodall.ch for general inquiries JG

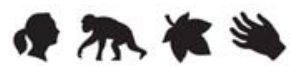

Jane Goodall Institut Schweiz
Jane Goodall Institute Schweiz

Postfach 2807

8033 Zürich

switzerland 
loading in rivers, attributed to lavaka formation, is described as the "land bleeding into the sea" (Helfert and Wood 1986). The problems caused by erosion in Madagascar are legion. High sediment loads cause rapid siltation in estuaries, lavaka formation destroys agricultural land and collapses roads, and sediment gravity flows issuing from active lavakas swamp tilled fields, ruining crops. It is asserted that "man is essentially to blame" (Randrianarijaona 1983) for erosion as a result of overgrazing, grassland burning, deforestation, and cart track formation (Tricart 1953, Riquier 1954, Petit and Bourgeat 1966, Hurault 1971, Hoeblich and Hoeblich 1983, Andriamampianina 1985, Gade 1996). International aid organizations describe the erosion as emblematic of human-caused environmental degradation and part of the overall threat to the ecology and biodiversity of Madagascar (e.g., USAID 2000, 2002).

The role of humans as the cause of deforestation is engrained as conventional wisdom, and has its origins rooted in the French colonial pre-conceived notions of human impact on the Malagasy landscape (Kull 2000). It is asserted that the central highlands were deforested by human activity over the last 2000 years (Klein 2002 and references therein). It is also asserted that the erosion features (lavakas) in the central highlands are a result of overgrazing, and that the deforestation on the central highlands represents one of the most severely affected habitats not only in Madagascar but the world (Wells and Andriamihaja 1993, Kull 2000, Klein 2002). The abundance of lavakas in the highlands and the large suspended load of Malagasy rivers during the wet season are often cited as a testament to deforestation and related erosion in the central highlands (Randrianarijaona 1983, Helfert and Wood 1986). There are, in fact, few or no data on erosion rates or bulk sediment transport rates, and so these assertions are unsubstantiated. Gradual data acquisition in the last 20 years reveals that the story of landscape evolution in Madagascar is not simple, and that the role of humans is less clear. Palynological investigations of lake cores that span the Holocene suggest that patchy forest interspersed with grassland was characteristic of the central highlands prior to the arrival of the first humans (Burney 1987abc, 1988). Charcoal is also found in the portion of the stratigraphic section that pre-dates the arrival of humans. This suggests that the grassland was maintained by the natural occurrence of fire (MacPhee et al. 1985, Burney 1987abc, 1988), and that the central highlands may not have been deforested by human activity (Kull 2000, Klein 2002). The population of the central highlands may be using fire to maintain a habitat that was already present when their ancestors first arrived in Madagascar.

The role of humans in lavaka formation and massive erosion is also in question. Only $25 \%$ of lavakas studied have been directly linked to human activity, whereas about $20 \%$ have clear non-anthropogenic causes (Wells and Andriamihaja 1993). Both the proximal and ultimate causes of most lavakas studied remain undetermined (Wells and Andriamihaja 1993). Human activities may well exacerbate erosion and lavaka formation (Tricart 1953, Riquier 1954, Petit and Bourgeat 1966, Wells and Andriamihaja 1993, 1997, Raharijaona-Raharison and Randrianarison 1999, Cox et al. 2003, 2004), but there is evidence that lavakas pre-date the 2,000-year human occupation of Madagascar (Bourgeat and Ratsimbazafy 1975, Hoeblich and Hoeblich 1983, Wells and Andriamihaja 1993, 1997, Cox et al. 2009).
Wells et al. (1991) and Wells and Andriamihaja $(1993,1997)$ proposed a series of five phases to describe the formation of lavakas. Type I lavaka are initiated mid-slope and are identified by the amphitheater-like steep walls of the incipient lavaka as a result of the in situ collapse of a soil surface. The collapse of the soil surface in the Type I lavaka is different from mass wasting because the intact soil surface of the lavaka is displaced downward, in contrast to the flow and mixing of the soil parallel to the angle of the slope that generally takes place in a mass wasting event. The Madagascar highlands has undergone Neogene to Holocene uplift (Pique et al. 1999, de Wit 2003), this has generated steep terrain with a thin lateritic soil which rests on a saprolitic mantle 10s of meters thick. Cox et al. (2004) have proposed this is due to groundwater sapping. The sapping is initiated at the beginning of the wet season via deep fissures or cracks in the soil, which form naturally during the dry season (soils during the dry season hold less than $5 \%$ moisture), or may be caused by animal or human footpaths. These fissures or cracks provide a direct avenue of ingress to the soil-saprolite interface. The sapping creates underground caverns at this interface and is followed by the collapse of the soil surface and the initial formation of the lavaka.

After Type I lavaka formation, a Type II lavaka forms a drainage incisions at the lowest down slope point of the lavaka, from which the underlying and surficial soils erode into the existing drainage basins. Sediment volumes on the order of $8,000 \mathrm{~m}^{3}$ occur in a few months and are responsible for the high bed loads observed in Malagasy rivers (Cox et al. 2003, 2004, 2009). During this phase high erosion rates strip the nutrient poor laterites down to the in situ saprolite providing a nutrient rich island of weathered saprolite that will subsequently support forest development.

Type III and IV lavakas show some peneplanation of the steep walls and the interior lavaka soils that were initially formed. Type III and IV lavaka are often identified by the welldeveloped vegetation in the lavaka.

The Type $V$ lavaka show further peneplanation of the bowl shaped feature, which is accompanied by soil nutrient depletion due to extended leaching, and the eventual degradation of the in situ forest and the re-invasion of the grassland.

The purpose of this investigation is to examine, a) the forest cover in the central highlands, b) the spatial configuration of the forest cover and $\mathrm{c}$ ) the role the natural occurring erosion features may play in the development of landscape evolution and vegetation patterning on the central highlands in Madagascar.

\section{METHODS}

SATELLITE DATA. Landsat Enhanced Thematic Mapper

Plus (ETM+) remote sensing data was acquired from 19 April 2003 for characterization of the landscape. ETM+ data have a 30 -meter spatial resolution and seven spectral bands ranging from the visible to the thermal infrared portion of the spectrum. A subset of the pseudo-color image illustrates the spatial pattern of vegetation in the study area. We georeferenced the image data to Universal Transverse Mercator (UTM) map coordinates.

LAND COVER CLASSIFICATION. We conducted GPS guided fieldwork to ground truth the geo-referenced training sites. The documented reference sites provided guidance for our interpretation of the classification of ETM+ image. We sampled localities at approximately $10 \mathrm{~km}$ intervals that included repre- 
sentative grassland, lavakas in various stages of succession and riparian forests in the vicinity of Madagascar Route Nationale (RN) 4 from Maevatanana to Mahatsinjo (Figure 1). During the field work, we recorded GPS points in UTM coordinates for each site with attribute descriptions and digital photographs. We then converted the UTM coordinates into a GIS point file using ESRI ArcGIS. The GIS data were on the ETM+ image so that the field sites and the attributes could be further examined to assist image classification and verification. As the landscape pattern is rather simple, we employed unsupervised classification on the ETM+ data for several sample sites to extract spectral signatures to use as training sites for classifying the entire image. Upon finishing the classification, we labeled the spectral clusters into general categories of lavaka, riparian, and grassland habitats and water.

SAMPLE SITE CHARACTERISTICS. We documented soil

characteristics including color using the Munsell Soil Color Chart, $\mathrm{pH}$, moisture content, soil compaction with a Lang penetrometer, and the angle of repose for each sample sites. We determined the number of plant taxa at each locality and used an analysis of variance to determine if species diversity was significantly different among the three habitats (Table 1). We also converted the known seismic epicenters for earthquakes that occurred between 1988 and 2004 into a GIS point file so that the possible seismic effects on the formation of erosion features could be observed through remote sensing data (Figure 1).

\section{RESULTS}

Many lavakas exhibit features indicative of ephemeral erosion features. In the present study we examined satellite data from the early 1980s, early 1990s and the data presented in this paper is from April 2003. We were unable to identify, using these data, the formation of new lavakas in our study region during this 20-25 year interval. This unexpected observation raises an important question regarding lavaka longevity. We assumed their age was at least as old as the oldest trees found in many

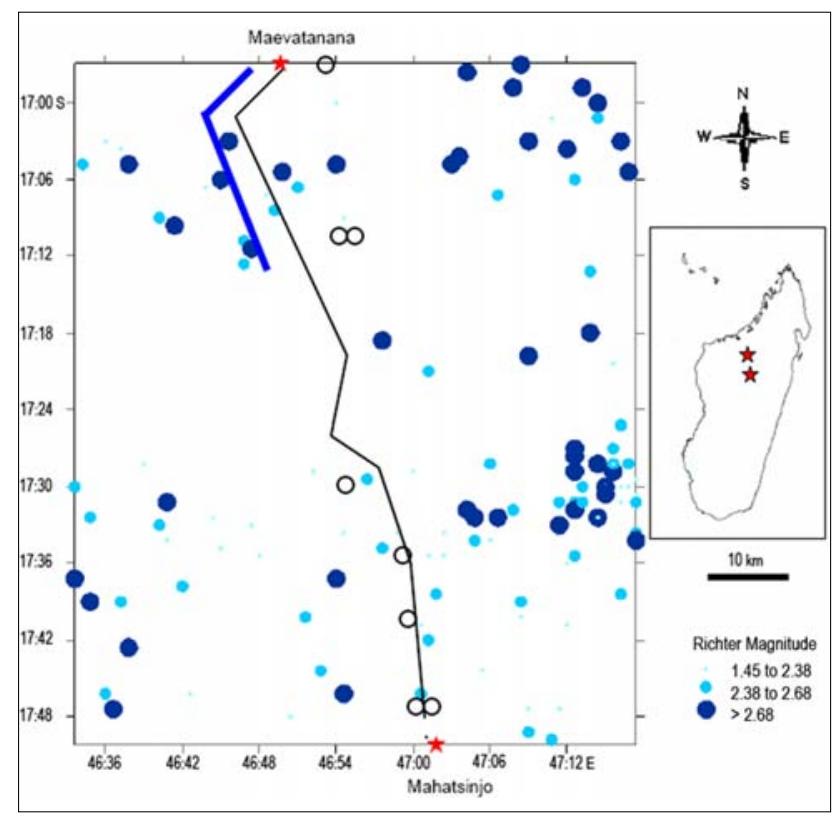

FIGURE 1. Map showing location of the study region and the RN4 (thin black line), which served as a sampling line in the study area. The distribution of the epicenters of earthquakes and their magnitude are indicated in blue. The sampled lavakas are indicated by open circles; note that the high frequency of lavakas are in the most seismically active areas. The thick blue line is the location of the Betsiboka River. of the Type III and IV lavakas. Cox et al. (2004, 2009), based on $\mathrm{C}^{14}$-dates of sub-fossil plant material in deposits of the lavakas, suggest that the time frame for the growth and development of Type I-V lavakas may be in the thousands of years. This is supported by the low recruitment of new erosional features spanning a 30-50 year photographic history in Cox's study area of the central highlands (Cox et al. 2009), and our own studies using satellite data from the early 1980s.

In the study region, three areas $(A, B, C)$ were chosen to determine the percentage of forest cover (Figure 2A-D). Classified Landsat ETM+ revealed the landscape characteristics of the study region (Figure 2A-D) and allowed us to determine the area covered by water, grassland and lavaka forest and riparian vegetation (Table 2). Forest cover for study area $A$ (Figures 2A, B, 3A-C, Appendix 2A, C, E), study area B (Figure $2 \mathrm{~A}, \mathrm{C}$ ) and study area $\mathrm{C}$ (Figure $2 \mathrm{~A}, \mathrm{D}$ ) are given in Table 2. The total area of each site is 93,636 ha.

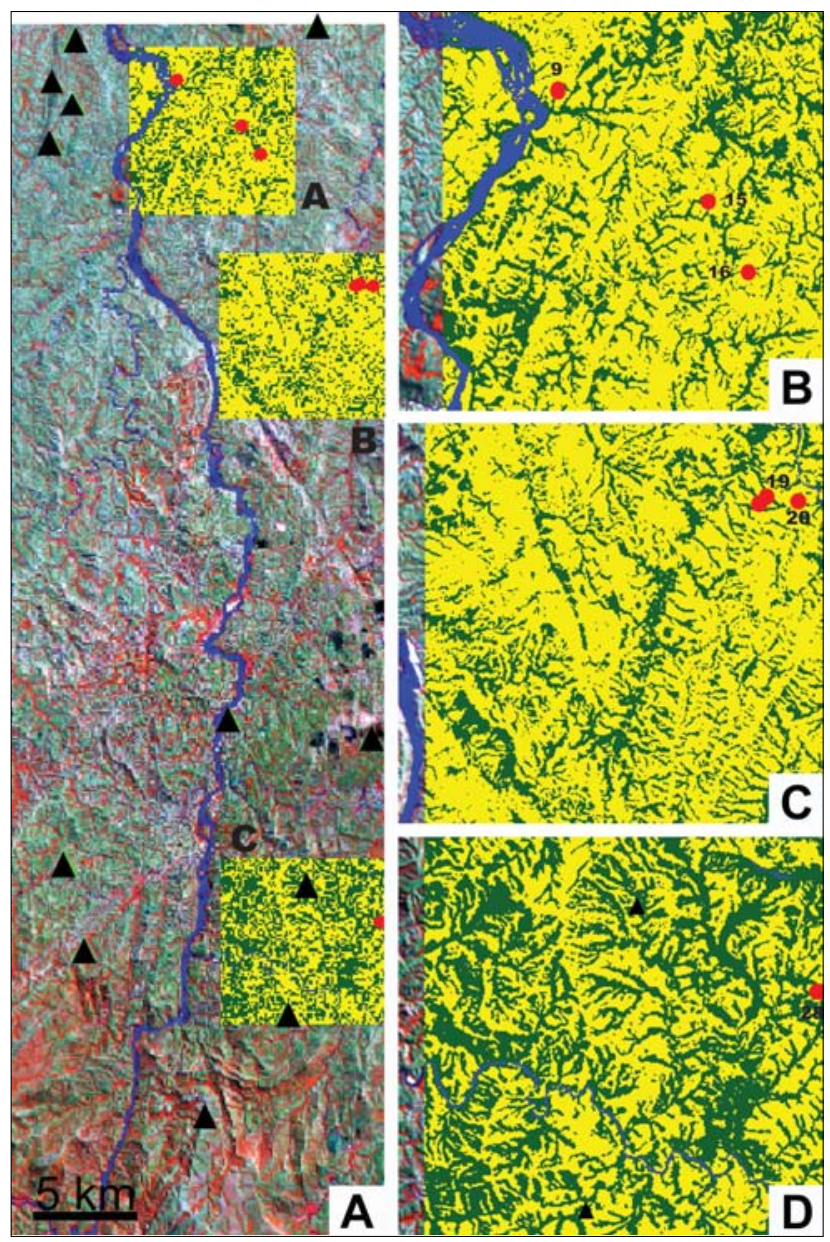

FIGURE 2A. The satellite image of the study region with the three areas A, B, and $C$ showing the grassland (yellow), lavaka and riparian forest (green), and water (blue). Study area A corresponds to Figure 2B, area B corresponds to Figure $2 \mathrm{C}$ and area $\mathrm{C}$ corresponds to Figure $2 \mathrm{D}$. The triangles show the epicenters of earthquakes over the past 25 years in this study of 3.0 Richter Magnitude or greater. Red dots are representative sample localities. FIGURE 2B. Study area A showing the distribution of grassland (yellow), lavaka and riparian forest (green) and water (blue). Site $9=$ Appendix $2 \mathrm{~A}$ Sample Site $15=$ Appendix $2 \mathrm{C}$, and Sample Site $16=$ Appendix 2E. The upper left hand corner of the figure has Longitude and Latitude coordinates

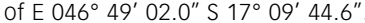

FIGURE $2 \mathrm{C}$. Study area B showing the distribution of grassland, lavaka and riparian forest and water. Sample Site $19=$ Appendix 2B, Sample Site $20=$ Appendix 2D. The upper left hand corner of the figure has Longitude and Latitude coordinates of E $046^{\circ} 51^{\prime} 47.9^{\prime \prime} \mathrm{S} 17^{\circ} 15^{\prime} 35.8^{\prime \prime}$.

FIGURE 2D. Study area C showing the distribution of grassland, lavaka and riparian forest and water. Sample Site $28=$ Appendix $2 F$. The upper left hand corner of the figure has Longitude and Latitude coordinates of $\mathrm{E} 046^{\circ}$ $52^{\prime} 00.7^{\prime \prime} \mathrm{S} 17^{\circ} 32^{\prime} 40.3^{\prime \prime}$. 
TABLE 1. Data collected at 35 ground-truthed sites in the study area, showing habitat type, longitude and latitude (degrees minutes seconds), elevation, Munsell soil color, the average of three readings taken with a Lang Penetrometer to describe compaction properties of the soil, soil moisture, pH, the angle of repose and the number of identified plant taxa at each locality.

\begin{tabular}{|c|c|c|c|c|c|c|c|c|c|}
\hline Site & Habitat & Coordinates & $\begin{array}{l}\text { Elevation } \\
\text { (m) }\end{array}$ & $\begin{array}{l}\text { Munsell Soil } \\
\text { Color }\end{array}$ & $\begin{array}{l}\text { Lang Penetrometer } \\
\text { (average of } 3 \\
\text { readings) }\end{array}$ & $\begin{array}{l}\text { Soil Moisture } \\
\text { Content }\end{array}$ & $\mathrm{pH}$ & $\begin{array}{l}\text { Angle of } \\
\text { Repose }\end{array}$ & $\begin{array}{l}\text { Number of } \\
\text { species } \\
\text { present }\end{array}$ \\
\hline 1 & Grassland & $\mathrm{E} 046^{\circ} 46^{\prime} 34.3^{\prime \prime} \mathrm{S} 17^{\circ} 01^{\prime} 01.5^{\prime \prime}$ & 85 & & & $<5 \%$ & & & 3 \\
\hline 2 & Grassland & E046 46' 50.6" S1700' 59.7" & 105 & $2.5 Y R \quad 4 / 6$ & 18 & $<5 \%$ & 6.9 & 5 & 2 \\
\hline 3 & Grassland & $\mathrm{E}^{\prime} 46^{\circ} 48^{\prime} 19.8^{\prime \prime} \mathrm{S} 17^{\circ} 00^{\prime} 43.1^{\prime \prime}$ & 128 & & & $<5 \%$ & & & 4 \\
\hline 4 & $\begin{array}{l}\text { Riparian } \\
\text { Forest }\end{array}$ & $\mathrm{E} 046^{\circ} 48^{\prime} 48.1^{\prime \prime} \mathrm{S} 17^{\circ} 02^{\prime} 43.8^{\prime \prime}$ & 158 & $2.5 Y R 3 / 0$ & 5.8 & $40 \%$ & 6.9 & & 16 \\
\hline 5 & $\begin{array}{l}\text { Riparian } \\
\text { Forest }\end{array}$ & E046 $48^{\prime} 10.1^{\prime \prime} \mathrm{S} 17^{\circ} 04^{\prime} 02.9^{\prime \prime}$ & 147 & & & & & & 7 \\
\hline 6 & Grassland & E046 $48^{\prime} 37.2^{\prime \prime} \mathrm{S} 17^{\circ} 04^{\prime} 58.1^{\prime \prime}$ & 214 & 10YR 6/6 & 15.5 & $<5 \%$ & 6.9 & 0 & 3 \\
\hline 7 & $\begin{array}{l}\text { Riparian } \\
\text { Forest }\end{array}$ & $\mathrm{E} 046^{\circ} 49^{\prime} 18.3^{\prime \prime} \mathrm{S} 17^{\circ} 08^{\prime} 15.9^{\prime \prime}$ & 266 & 2.5 YR $5 / 4$ & 9 & $<5 \%$ & 6.9 & 40 & 12 \\
\hline 8 & $\begin{array}{l}\text { Riparian } \\
\text { Forest }\end{array}$ & E0465ㅇ' $33.1^{\prime \prime} \mathrm{S} 17^{\circ} 10^{\prime} 43.9^{\prime \prime}$ & 269 & 2.5 YR $5 / 2$ & 9.5 & $<5 \%$ & & 43 & 19 \\
\hline 9 & Grassland & E046 50' 32.5" S17 10' 41.3" & 263 & $2.5 Y R 5 / 2$ & 19 & $<5 \%$ & 6.9 & & 4 \\
\hline 10 & Grassland & $\mathrm{E}^{\prime} 46^{\circ} 48^{\prime} 37.2^{\prime \prime} \mathrm{S} 16^{\circ} 59^{\prime} 57.4^{\prime \prime}$ & 131 & & & $<5 \%$ & & & 2 \\
\hline 11 & $\begin{array}{l}\text { Riparian } \\
\text { Forest }\end{array}$ & E046 48' 56.8" S1659' 04.3" & 82 & & & & & & 3 \\
\hline 12 & Grassland & E046 51' 13.9" S165 57' 02.5" & 78 & & & $<5 \%$ & & & 3 \\
\hline 13 & Lavaka & E0465 55' 19.4" S1657' 36.8" & 142 & $2.5 Y R 5 / 4$ & 14 & $<5 \%$ & 6.6 & 47 & 15 \\
\hline 14 & Grassland & E046 55' $19.9^{\prime \prime} \mathrm{S} 16^{\circ} 57^{\prime} 38.3^{\prime \prime}$ & 218 & 2.5 YR $5 / 6$ & 17.5 & $<5 \%$ & 6.2 & 0 & 8 \\
\hline 15 & Grassland & $\mathrm{E}^{\prime} 46^{\circ} 52^{\prime} 28.1^{\prime \prime} \mathrm{S} 17^{\circ} 11^{\prime} 58.9^{\prime \prime}$ & 353 & & & $<5 \%$ & & & 2 \\
\hline 16 & $\begin{array}{l}\text { Riparian } \\
\text { Forest }\end{array}$ & E046 52' 59.7" S17²12' 48.3" & 306 & & & & & & 1 \\
\hline 17 & Lavaka & E046 55' 53.3" S17 16' 32.1" & 396 & & & $<5 \%$ & & & 10 \\
\hline 18 & Grassland & E046 55' 53.6" S17 16' 31.5" & 403 & 2.5 YR $5 / 4$ & 18.5 & $<5 \%$ & 6.8 & 47 & 3 \\
\hline 19 & Lavaka & E046 55' 58.8" S17 $16^{\circ} 26.9^{\prime \prime}$ & 409 & & & $<5 \%$ & & & 4 \\
\hline 20 & $\begin{array}{l}\text { Riparian } \\
\text { Forest }\end{array}$ & $\mathrm{E}^{2} 46^{\circ} 56^{\prime} 22.3^{\prime \prime} \mathrm{S} 17^{\circ} 16^{\prime} 30.1^{\prime \prime}$ & 361 & $2.5 Y R 5 / 6$ & 11.4 & $<5 \%$ & & 35 & 13 \\
\hline 21 & $\begin{array}{l}\text { Riparian } \\
\text { Forest }\end{array}$ & E046 $57^{\prime} 29.0^{\prime \prime} \mathrm{S} 17^{\circ} 27^{\prime} 01.5^{\prime \prime}$ & 576 & & & & & & 9 \\
\hline 22 & Grassland & $\mathrm{E}^{\prime} 46^{\circ} 59^{\prime} 48.1^{\prime \prime} \mathrm{S} 17^{\circ} 28^{\prime} 43.1^{\prime \prime}$ & 607 & & & & & & 3 \\
\hline 23 & Grassland & E046 58' 43.9" S17² 29' 43.6" & 620 & $2.5 Y R \quad 4 / 6$ & 18 & $<5 \%$ & 6.6 & & 2 \\
\hline 24 & Grassland & E046 57' 50.1" S17²32' 58.3" & 685 & $2.5 Y R 5 / 6$ & 18 & $<5 \%$ & 6.9 & 47 & 2 \\
\hline 25 & $\begin{array}{l}\text { Riparian } \\
\text { Forest }\end{array}$ & E046 57' 55.4" S17³2' 56.1" & 694 & $2.5 Y R 5 / 6$ & 13 & $<5 \%$ & 6.5 & & 15 \\
\hline 26 & Lavaka & E046 57' 26.4" S17²33' 38.7" & 719 & & & & & 47 & 9 \\
\hline 27 & Grassland & $\mathrm{E}^{2} 46^{\circ} 56^{\prime} 48.7^{\prime \prime} \mathrm{S} 17^{\circ} 34^{\prime} 34.6^{\prime \prime}$ & 698 & & & & & & 3 \\
\hline 28 & $\begin{array}{l}\text { Riparian } \\
\text { Forest }\end{array}$ & E046 56' 50.1" S17³4' 34.1" & 699 & & & & & & 15 \\
\hline 29 & Grassland & E046 57' 29.6" S17³8' 06.5" & 661 & $2.5 Y R 5 / 6$ & 18.5 & $<5 \%$ & 6.8 & 5 & 2 \\
\hline 30 & Lavaka & E046 57' 30.3" S17³8' 05.3" & 653 & $2.5 Y R \quad 4 / 2$ & 14 & $<5 \%$ & 6.5 & & 18 \\
\hline 31 & Lavaka & E046 59' 27.6" S17²41' 50.3" & 841 & & & & & & 8 \\
\hline 32 & Grassland & $\mathrm{E}^{2} 47^{\circ} 01^{\prime} 08.5^{\prime \prime} \mathrm{S} 17^{\circ} 46^{\prime} 47.5^{\prime \prime}$ & 1,127 & & & $<5 \%$ & & & 2 \\
\hline 33 & Lavaka & $\mathrm{E} 047^{\circ} 01^{\prime} 26.3^{\prime \prime} \mathrm{S} 17^{\circ} 48^{\prime} 44.8^{\prime \prime}$ & 1,202 & & & $<5 \%$ & & & 9 \\
\hline 34 & Lavaka & E047º $01^{\prime} 43.8^{\prime \prime}$ S17 50' 12.5" & 1,448 & & & $<5 \%$ & & & 10 \\
\hline 35 & Grassland & E0470 01' 44.4" S170 50' 11.9" & 1,451 & & & $<5 \%$ & & & 2 \\
\hline
\end{tabular}

Forest cover distribution in the study sites consists of two types: Forests associated with riparian habitats (Figure 3C, Appendix 2A, D, arrows), and forest fragments associated with lavakas (Figure $3 \mathrm{C}$, arrow heads, Appendix 1B, Appendix 2B).

Grassland, riparian and lavaka habitats (sampled during the dry season) have 85 identifiable species associated with the habitats. Grasslands consistently had an average of 2.94 species
$(S D=1.48)$. Two species of grass, Heteropogon contortus (L.) P. Beauv. ex Roem. \& Schult and Hyparrhenia rufa (Nees) Staph are associated with a majority of the sites. Riparian habitats had an average of 10.9 taxa ( $S D=5.72$ ), and lavakas averaged 10.38 taxa ( $S D=4.31$ ) per location and are not significantly different. The number of taxa associated with riparian and lavaka habitats are significantly higher than the number of taxa in grasslands (Table 1, Figure 4). 
TABLE 2. Percentages of water (blue), lavaka / riparian forest (green) and grassland (yellow) of the 93,636 ha at study sites A, B, and C, in Figures 2A.

\begin{tabular}{|l|c|c|c|}
\hline Habitat & Study Area A & Study Area B & Study Area C \\
\hline Water & $3899(4.2 \%)$ & $119(0.1 \%)$ & $983(1.1 \%)$ \\
\hline $\begin{array}{l}\text { Lavaka- } \\
\text { Riparian Forest }\end{array}$ & $25201(26.9 \%)$ & $24428(26 \%)$ & $44339(47.4 \%)$ \\
\hline Grassland & $64536(68.9 \%)$ & $69089(73.8 \%)$ & $48314(51.6 \%)$ \\
\hline
\end{tabular}

Soil color, moisture content, and $\mathrm{pH}$ are all very similar among the three habitats and exhibit no significant differences (Table 1). Soil compaction, however, is severe in the grasslands habitats (averaging a Lang penetrometer reading of $17.9, \mathrm{SD}=1.1$ ), and is significantly lower in the lavakas (two readings that average 14), and riparian habitats (average 9.7, SD = 2.7) (Table 1, Figure 5).

\section{DISCUSSION}

Lavaka formation has been attributed to human activity, particularly deforestation, controlled burns and wildfire (Appendix 1A). It has been assumed that the deforestation of the central highlands is a result of a combination of the above factors and poor environmental management. There is no doubt that erosion from the lavakas contribute to the high bed loads observed in the rivers during the wet season. However, only a small percentage of these geomorphic features can unequivocally be linked to human activity. The formation, maintenance, and succession of lavakas may represent a natural geomorphic phenomenon resulting from climatic patterns (strong wet and dry season) (Appendix 1B), edaphic features, ongoing tectonic uplift of the central highlands that maintains
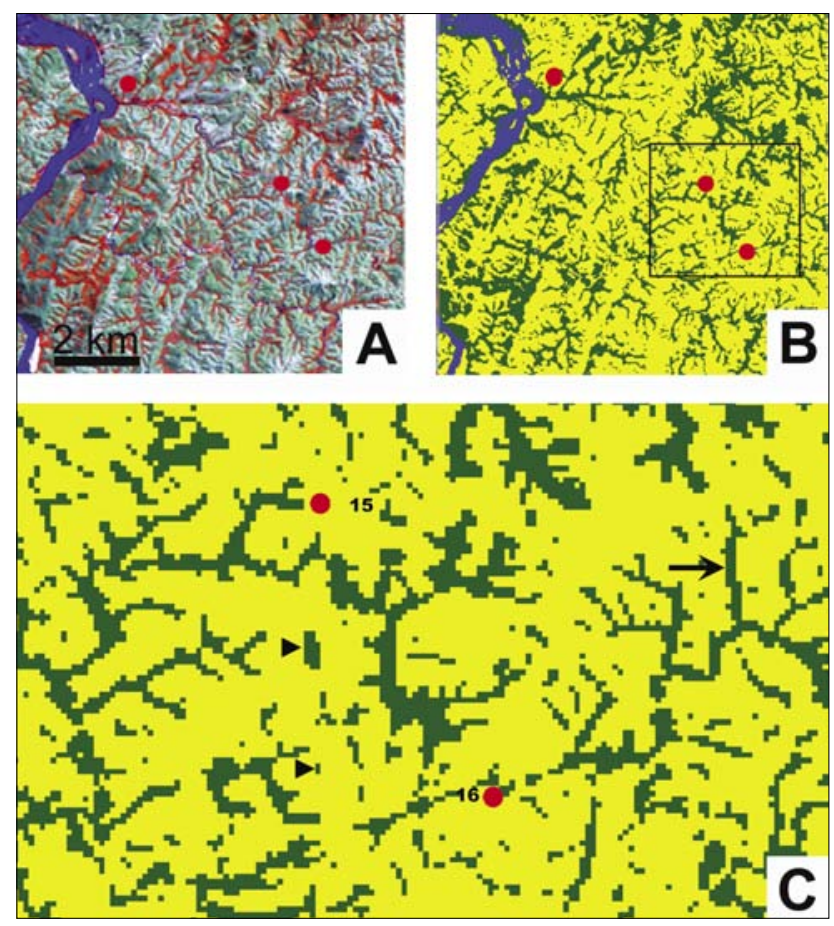

FIGURE 3A. Satellite image of a smaller area of study area A showing the location of some of the sample sites.

FIGURE 3B. Same area as in Figure 3A showing the distribution of grassland, lavaka and riparian forest, and water. The area inside the box is also in Figure 2A area $\mathrm{A}$ and Figure 2B.

FIGURE 3C. The area outlined in Figure 3B showing the distribution of grassland (yellow) and, lavaka and riparian forest (green). Note the long linear nature of riparian vegetation (arrow) and the numerous isolated lavaka forests interspersed between the continuous riparian vegetation (arrowheads). The upper left hand corner of the figure has Longitude and Latitude coordinates of E $046^{\circ} 51^{\prime} 46.5^{\prime \prime} \mathrm{S} 17^{\circ} 11^{\prime} 32.6^{\prime \prime}$.

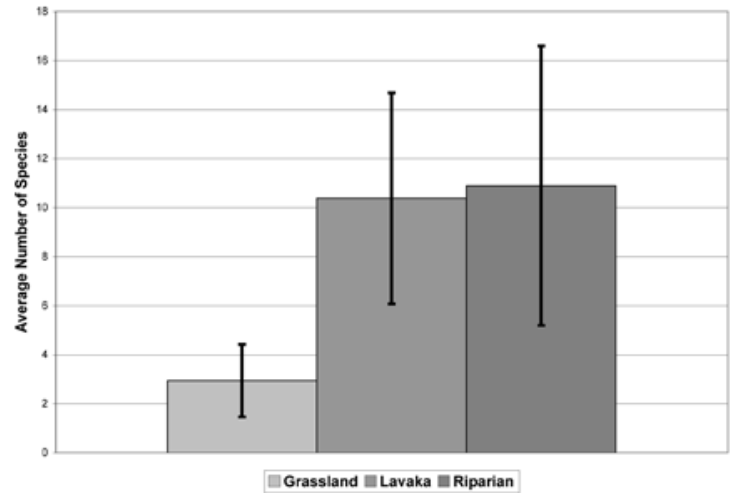

FIGURE 4. Average number of species in each habitat type. The lavaka and riparian habitats have significantly more taxa than the grasslands (the 0.01 confidence interval is indicated by the vertical bars).

a high angle of repose (Table 1), groundwater sapping, and continuous seismic activity (Figure 1) (Wright 1974, de Wit 2003).

The present study attempted to determine recruitment of new erosion features over a 20-25 year-period by comparison of a 1984 Landsat Thematic Mapper satellite data with the 2003 ETM+ data. We found no new recruitment of features in our study area suggesting that all of the current features exceed an age of 20 years. Recent $\mathrm{C}^{14}$-dating of carbon derived from lavakas in other areas of the central highlands indicate an age in the thousands of years for some lavakas, suggesting lavakas may be older than the first human occupation (Cox et al. 2009), and may represent geomorphic features much more persistent than previously suspected (Wright 1974).

Charcoal has been found in lake cores suggesting that wildfire was a disturbance factor prior to human occupation (MacPhee et al. 1985, Burney 1987abc, 1988, 1993). This also suggests that although humans continue to use fire, they may be doing so to manage the habitats of the central highlands by simulating and controlling a disturbance factor that was already in place when humans first arrived in Madagascar (Wright 1974).

The present study indicates that the vegetation associated with riparian habitats and with Type II-IV lavakas (Wells et al. 1991, Wells and Andriamihaja 1993, 1997) comprises $24-45 \%$ of the forest cover on the central highlands (Appendix $1 \mathrm{~B}$, Table 2). Often, the initial formation of lavakas and the successional vegetation that they harbor are isolated from the main drainage basin (Figure 3C,Appendix 1C). If lavakas are as long lived

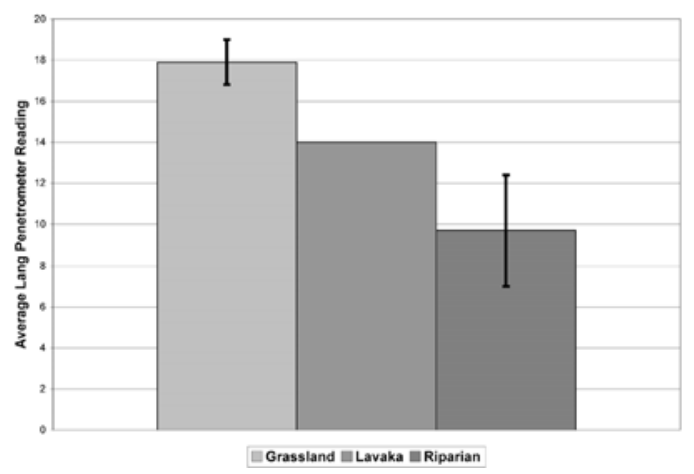

FIGURE 5. The average Lang pentronmeter readings for each habitat type. Grasslands exhibit significantly greater soil compaction than the riparian habitat (the 0.01 confidence interval is indicated by the vertical bars).

The average reading for the two lavakas sampled were exactly the same, which is below the grasslands and similar to the riparian habitat; however, there were too few average readings in the lavakas to establish a reliable confidence interval. 
as the data suggests, their vegetation may also be genetically isolated from the more continuous riparian forests. Depending on pollination biology of the individual taxa, this may restrict gene flow among the isolated forest populations in the lavakas (e.g., Wright 1974, Shaffer 1981, Pimm et al. 1988, Honnay et al. 1999). Rivers and watersheds as isolating features have been hypothesized as playing an important role in contributing to Madagascar's biodiversity (Martin 1972, Goodman and Ganzhorn 2004, Pastorini et al. 2005, also see Pearson and Raxworthy 2009) and the isolating effects of watersheds that traverse elevational changes may be intensified especially during periods of climatic change (Wilmé et al. 2006).

The association of forests in the central highlands with riparian and lavaka habitats, and the lack of forest cover on adjacent grassland, or the occurrence of successional vegetation associated with grassland suggests that the forest development may be associated with changes in soil moisture availability (Pennington et al. 2000). Soils associated with lavakas, riparian and grassland habitats were tested for moisture content during the dry season. Moisture content was similar in all habitats suggesting that soil moisture may not be a major factor in vegetation patterning (Table 1).

Nutrient availability plays a role in vegetation patterning (Pennington et al. 2000). Lavakas are believed to form by the collapse of the soil surface due to groundwater sapping at the soil-saprolite interface. The ground water sapping appears to be gradual and incremental (Appendix 1B) in lavakas that are isolated from human activity. As ground water sapping continues to efface the nutrient poor soils, the root zone comes into closer and closer proximity to the less nutrient poor saprolite and ground water. Such a process may initiate the development of Type II-IV lavakas that characteristically have well developed vegetation in comparison with the nutrient poor grasslands (Appendix 1B, C).

Another difference between lavaka and riparian habitats and the grasslands is the significant difference in soil compaction (Figure 5). Soil penetrometers mimic plant roots. The higher the penetrometer reading the greater the compaction and greater the difficulty plant roots have penetrating the soil. Grasslands exhibited high readings (average of 17.9), a compaction profile that may limit the ability of a variety of species to establish root growth (Table 1, Figure 5). This reading in an agricultural situation would require deep tillage to promote plant root growth and establishment of the crop plant. Lavaka and riparian habitats have average readings of 14 and 9.7 , respectively, readings within a range that permits root establishment (Table 1, Figure 5). Thus, differences in vegetation patterning and diversity may be due to the ability of plants to establish root growth. There is an inverse relationship between species diversity and soil compaction in the three habitats (Figures 4,5). The mobility of the soils in lavaka and riparian habitats may relieve surficial and subsurface compaction and naturally simulate tilling.

It is interesting that the people of the central highlands often place their tiered and cultivated fields down slope of the drainage incisions of the lavaka (Appendix 1D, arrow). The placement of these agricultural fields may receive the benefit of improved soil moisture due to run off from the lavaka, improved nutrient availability due to the erosion of the exposed saprolite in the lavaka, and the mobility of these soils may relieve soil compaction permitting better root establishment. This practice may slow erosion rates and reduce bed loads. Future investigation will focus on characterizing edaphic differences between the lavaka and riparian, and the grassland habitats.

\section{CONCLUSIONS}

There is no doubt that human activity in Madagascar is changing the fauna, flora and the landscape. Lavakas may be natural and long-lived geomorphologic phenomena, and may represent a dynamic and novel habitat. It is important to determine if natural occurring lavakas and those induced by human activity have different developmental processes and what role the various erosion features play in the development of Madagascar's floristic and faunal diversity, and landscape evolution.

\section{ACKNOWLEDGEMENTS}

We would like to thank Rónadh Cox for her continuing cooperation and collaboration on the formation of Malagasy lavaka. The NASA Rhode Island Space Grant Consortium provided funding for purchasing the Landsat imageries, and the National Geographic Society for funding the field portion of the study. All of the field work was done as an adjunct under the permits and direction of the Missouri Botanical Garden. I would like to thank all of Missouri's research team in Madagascar that were helpful in facilitating the field research. I thank three anonymous reviewers for their detailed reviews of the manuscript and for providing helpful comments that greatly improved the manuscript.

\section{REFERENCES}

Andriamampianina, N. 1985. Les lavaka malgaches : leur dynamique érosive et leur stabilisation. Madagascar Revue de Géographie 46: 69-85.

Bourgeat, F. \& Ratsimbazafy, C. 1975. Retouches à la chronologie du Quaternaire continental de Madagascar. Conséquences sur la pédogenèse. Bulletin de la Société Géologique de France 17: 554-561.

Burney, D. 1987a. Pre-settlement vegetation changes at Lake Tritrivakely, Madagascar. Palaeoecology of Africa and Surrounding Islands, 18: 357-381.

Burney, D. 1987b. Late Holocene vegetational change in central Madagascar. Quaternary Research 28: 130-143.

Burney , D. 1987c. Late Quaternary stratigraphic charcoal records from Madagascar. Quaternary Research 28: 274-280.

Burney, D. 1988. Modern pollen spectra from Madagascar. Palaeogeography, Palaeoclimatology, Palaeoecology 66: 63-75.

Burney, D. 1993. Late Holocene environmental changes in arid southwestern Madagascar. Quaternary Research. 40: 98-106.

Cox, R., Rakotondrazafy, A. F. M. and Bakoariniaina, L. N. 2003. Geological controls on development of erosional gullies (lavaka), central Madagascar. Geological Society of America Abstracts 35, 6: 64. (doi:10.1086/598945)

Cox, R., Rakotondrazafy, A. F. M. and Rakotondramazava, H. T. 2004. Geological versus human controls on lavaka formation and extreme erosion in Madagascar. Geological Society of America Abstracts 36, 5: 171.

Cox, R. Bierman, P, Jungers, M. C. and Rakotondrazafy, A. F. M. 2009. Erosion rates and sediment sources in Madagascar inferred from ${ }^{10} \mathrm{Be}$ analysis of lavaka, slope and river sediment. The Journal of Geology, 117: 363-376. (doi:10.1086/598945)

de Wit, M. J. 2003. Madagascar: Heads it's a continent, tails it's an island. Annual Review of Earth and Planetary Sciences 31: 213-248. (doi:10.1146/annurev.earth.31.100901.141337)

Enquêtes Prioritaires auprès des Ménages. 1999. Rapport principal 2000. Antananarivo, Institut National de la Statistique (INSTAT) 191.

Gade, D. W. 1996. Deforestation and its effects in highland Madagascar. Mountain Research and Development, 16, 2: 101-116.

Goodman, S. M. and Ganzhorn, J. U. 2004. Biogeography of lemurs in the humid forests of Madagascar: The role of elevational distribution and rivers. Journal of Biogeography 31, 1: 47-55. (doi:10.1111/j.13652699.2004.00953.X) 
Helfert, M. R. and Wood, C. A. 1986. Shuttle photos show Madagascar erosion. Geotimes 31: 4-5.

Hoeblich, J. \& Hoeblich, J.-M. 1983. L'organisation du relief dans les environs de Tananarive. Madagascar Revue de Géographie 43: 11-39.

Honnay, O., Endels, P., Vereecken, H. and Hermy, M. 1999. The role of patch area and habitat diversity in explaining native plant species richness in disturbed suburban forest patches in northern Belgium. Diversity and Disturbance 5: 129-141.

Hurault, J. 1971. La signification morphologique des lavaka. Revue de Géomorphologie Dynamique 20: 121-128.

Klein, J. 2002. Deforestation in the Madagascar highlands - established 'truth' and scientific uncertainty. GeoJournal 56: 191-199. (doi:10.1023/ A:1025187422687)

Kull, C. A. 2000. Deforestation, erosion, and fire: Degradation myths in the environmental history of Madagascar. Environment and History 6, 4: 423-450. (doi:10.3197/096734000129342361)

MacPhee, R. D. E. and Burney, D. A. 1991. Dating of modified femora of extinct dwarf Hippopotamus from southern Madagascar: Implications for constraining colonization and vertebrate extinction events. Journal of Archeological Science 18, 6: 695-706

MacPhee, R. D. E., Burney, D. A. and Wells, N. A. 1985. Early Holocene chronology and environment of Ampasambazimba, a Malagasy subfossil Lemur site. International Journal of Primatology 6, 5: 463-489. (doi:10.1007/BF02735571)

Martin, R. D. 1972. Adaptive radiation and behavior of the Malagasy lemurs. Philosophical Transactions of the Royal Society of London, Series B, Biological Sciences 264, 862: 295-352.

Pastorini, J., Thalman, U. and Martin, R. D. 2003. A molecular approach to comparative phylogeography of extant Malagasy lemurs. Proceedings of the National Academy of Sciences of the United States of America 100, 10: 5879-5884. (doi:10.1073/pnas.1031673100)

Pennington, R. T., Prado, D. E., and Pendry, C. A. 2000. Neotropical seasonally dry forests and Quaternary vegetation changes. Journal of Biogeography 27, 2: 261-273. (doi:10.1046/j.1365-2699.2000.00397.x)

Pearson, R. G. and Raxworthy, C. J. 2009. The evolution of local endemism in Madagascar: Watershed versus climatic gradient hypothesis evaluated by null biogeographic models. Evolution 63, 4: 959-967. (doi:10.1111/ j.1558-5646.2008.00596.X)

Petit, M. \& Bourgeat, F. 1966. Étude morphologique du bassin versant de la Tafaina (centre de Madagascar). Comptes Rendus de la Semaine Géologique de Madagascar 1965: 9-12.

Pimm, S. L., Jones, H. L., and Diamond, J. 1988. On the risk of extinction. The American Naturalist 132: 757-785. (doi:10.1086/284889)
Pique, A., Laville, E., Chotin, P., Chorowicz, J., Rakotondraompiana, S. \& Thouin, C. 1999. L'extension à Madagascar du Néogène à l'Actuel : arguments structuraux et géophysiques. Journal of African Earth Sciences 28, 4: 975-983.

Raharijaona-Raharison, L. J. \& Randrianarison, J. 1999. Facteurs géologiques et climatiques influençant l'érosion en lavaka et ensablement des rizières: le cas du massif d'Ambohitrandriampotsy du sud du Lac Alaotra. In: Actes du 4e colloque international organisé par l'Association pour les Montagnes Africaines (AMA). H . Hurni \& J. Ramamonjisoa (eds.), pp 159-172. Association pour les Montagnes Africaines, Antananarivo.

Randrianarijaona, P. 1983. The erosion of Madagascar. Ambio 12, 6: 308-311.

Riquier, J. 1954. Étude sur les "lavaka". Mémoires de I'Institut Scientifique de Madagascar 6: 169-189.

Shaffer, M. L. 1981. Minimum population sizes for species conservation. Bioscience 31, 2: 131-134.

Tricart, J. 1953. Érosion naturelle et érosion anthropogène à Madagascar. Revue de Géomorphologie Dynamique 5: 225-230.

United States Agency International Development (USAID), 1998. USAID Congressional Presentation FY 1998. Madagascar.

United States Agency International Development (USAID), 2000, USAID Congressional Presentation FY 2000. Madagascar.

United States Agency International Development (USAID), 2002, USAID Congressional Presentation FY 2002. Madagascar.

Wells, N. A., Andriamihaja, B. and Rakotovololona, H. F. S. 1991. Patterns of development of lavaka, Madagascar's unusual gullies. Earth Surface Processes and Landforms 16, 3: 189-206. (doi:10.1002/ esp.3290160302)

Wells, N. A. and Andriamihaja, B. 1993. The initiation and growth of gullies in Madagascar: are humans to blame? Geomorphology 8, 1: 1-46.

Wells, N. A. and Andriamihaja, B.. 1997. Extreme gully erosion in Madagascar and its natural and anthropogenic causes. In: Natural Change and Human Impact in Madagascar. S. M. Goodman and B. D. Patterson (eds.), pp 44-47. Smithsonian Institution Press, Washington.

Wilmé, L., Goodman, S. M., and Ganzhorn, J. U. 2006. Biogeographic evolution of Madagascar's microendemic biota. Science 312: 1063-1065. (doi:10.1126/science.1122806)

World Bank, USAID, Coopération Suisse, UNESCO, UNDP, and WWF. 1986. Madagascar Environmental Action Plan Vol. 1, Analysis and Advisory Work Report No. E21.

Wright Jr., H. E. 1974. Landscape development, forest fires, and wilderness management. Science 186: 487-495. (doi:10.1126/science.186.4163.487) 


\section{APPENDIX}

\section{APPENDIX 1}

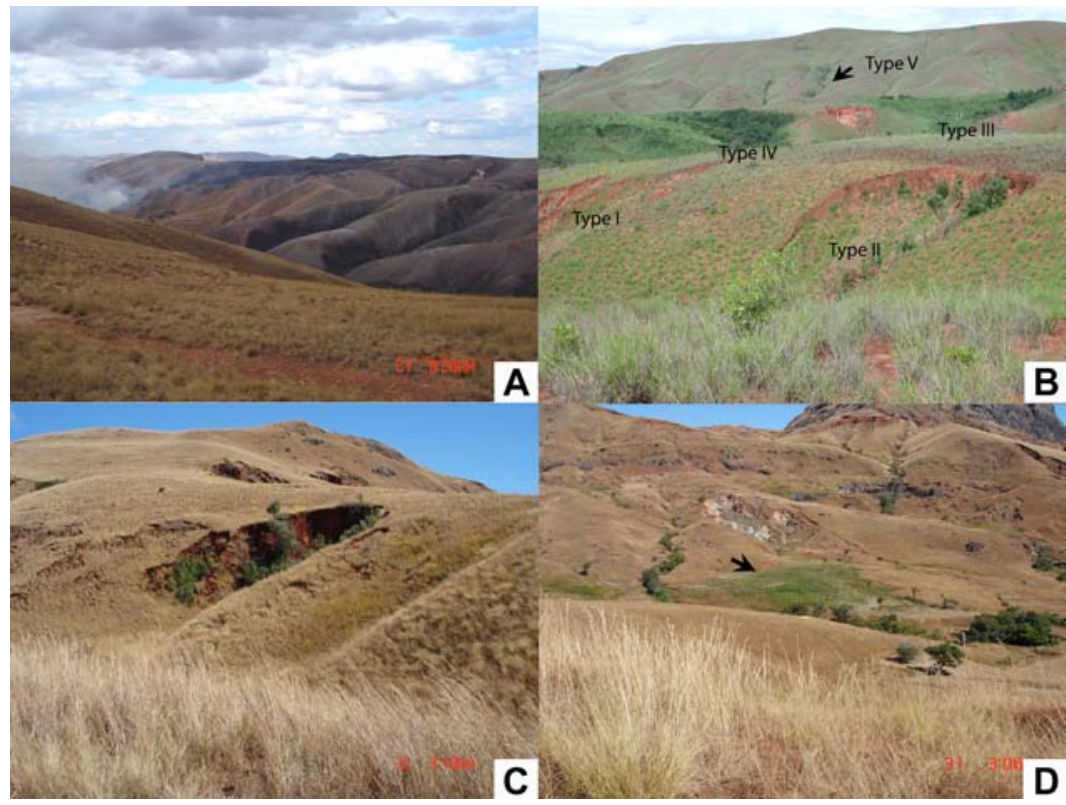

1A. Example of the widespread use of fire to maintain the grassland; these events may have been a natural feature of Madagascar prior to the arrival of humans. 1B. Lanscape photograph showing the development of Type I-V lavakas. Type I and II lavaka are characterized by the collapse of the soil surface leaving steep amphitheater like walls. Note the well developed vegetation in the Type III and IV lavakas in the background. Farther up slope and further in the background note the Type V lavakas showing the diminishing vegetation and the peneplanation of the steep side walls. 1C. A well developed Type III or IV lavaka showing steep side walls and the well developed vegetation in the lavaka. It is estimated that the development of lavaka may be on the order of thousands of years. 1D. Note the agricultural use of the splay deposit at the mouth of the thalweg (arrow). These agricultural modifications of the drainage egress of the lavaka reduce the erosional rates within the lavaka and have a stabilizing effect.

APPENDIX 2.

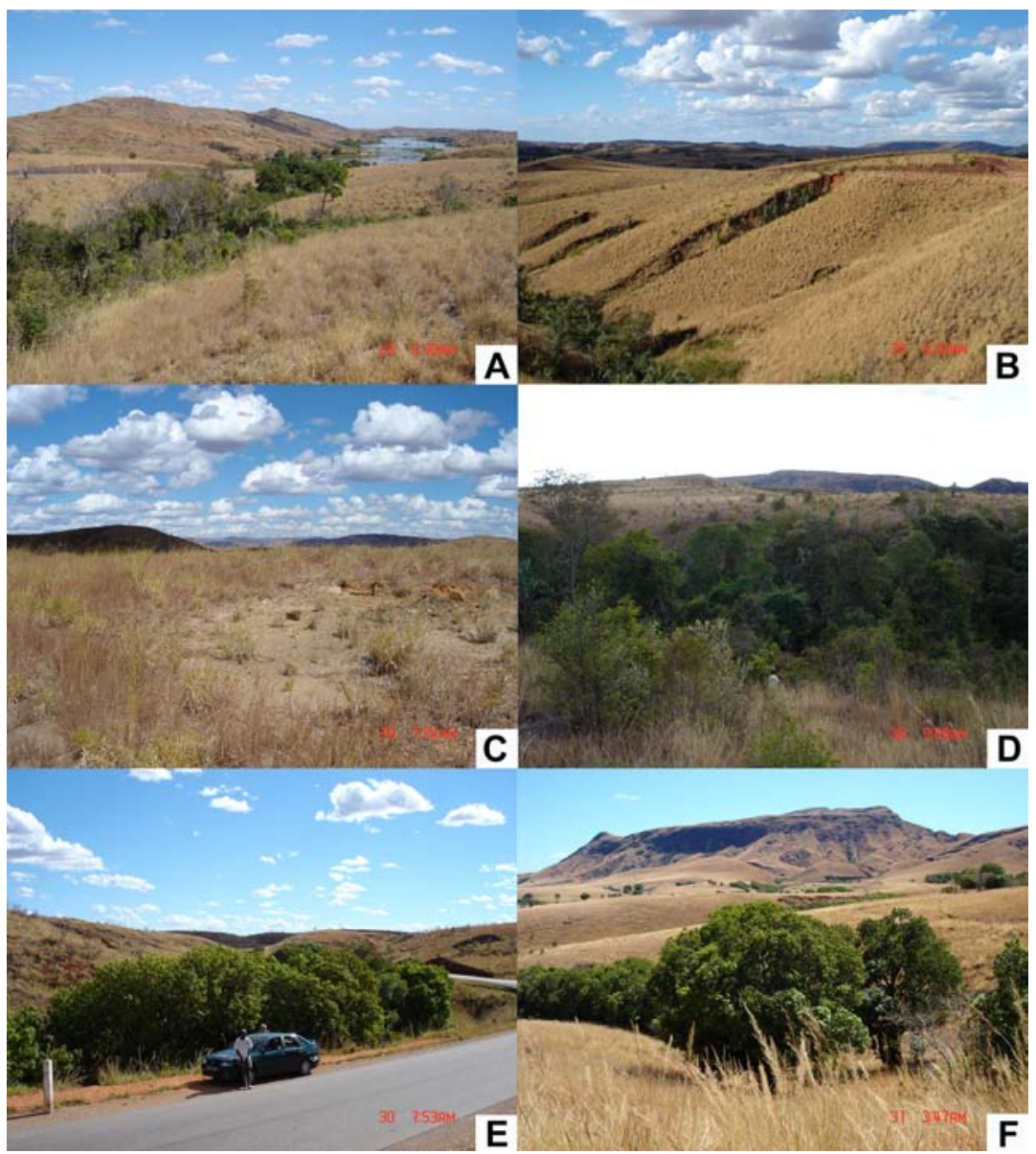

2A. Sample site 9 looking north showing riparian vegetation. 2B. Sample site 19 looking north showing a series of well defined lavakas with forest and the linear riparian vegetation on the bottom left. 2C. Sample site 15 looking east showing the grassland vegetation. 2D. Sample site 20 looking west showing the well developed riparian vegetation. $2 \mathrm{E}$. Sample site 16 looking west showing riparian vegetation with Mangifera indica Anacardiaceae occupying the riparian zone. 2F. Sample site 28 looking south showing an upslope riparian vegetation dominated by Mangifera indica. 